\title{
Article \\ Design and Test of a Miniature Hydrogen Production Integrated Reactor
}

\author{
Ion Velasco, Oihane Sanz *(D), Iñigo Pérez-Miqueo, Iñigo Legorburu and Mario Montes (D) \\ Department Applied Chemistry, University of the Basque Country (UPV/EHU), 20018 San Sebastian, Spain; \\ ionvelascoortiz@gmail.com (I.V.); inigo.perez@ehu.es (I.P.-M.); inigo.legorburu@ehu.eus (I.L.); \\ mario.montes@ehu.es (M.M.) \\ * Correspondence: oihane.sanz@ehu.eus
}

check for

updates

Citation: Velasco, I.; Sanz, O.; Pérez-Miqueo, I.; Legorburu, I.; Montes, M. Design and Test of a Miniature Hydrogen Production Integrated Reactor. Reactions 2021, 2, 78-93. https://doi.org/10.3390/ reactions 2020007

Academic Editors: Valérie Meille, Sibudjing Kawi, Francesco Frusteri and Luis M. Gandía

Received: 1 March 2021

Accepted: 12 April 2021

Published: 16 April 2021

Publisher's Note: MDPI stays neutral with regard to jurisdictional claims in published maps and institutional affiliations.

Copyright: (c) 2021 by the authors. Licensee MDPI, Basel, Switzerland. This article is an open access article distributed under the terms and conditions of the Creative Commons Attribution (CC BY) license (https:// creativecommons.org/licenses/by/ $4.0 /)$.
Abstract: A detailed study of the experimental issues involved in the design and operation of a methanol steam microreformer is presented in this paper. Micromachining technology was utilized to fabricate a metallic microchannel block coupling the exothermic and endothermic process. The microchannel block was coated with a $\mathrm{Pd} / \mathrm{ZnO}$ catalyst in the reforming channels and with $\mathrm{Pd} / \mathrm{Al}_{2} \mathrm{O}_{3}$ in the combustion channels by washcoating. An experimental system had been designed and finetuned allowing estimation of the heat losses of the system and to compensate for them by means of electric heating cartridges. In this way, the heat necessary for the reforming reaction is provided by methanol combustion, thanks to the temperature and flow cascade controller we developed. Thus, the coupling of both reactions in a block of microchannels without the interference caused by significant heat loss due to the small size of the laboratory microreactor could be studied. Runs of this microreformer device were carried out, varying the deposited catalyst amount, methanol steam reforming temperature and space velocity. When the reforming reaction was compensated by the combustion reaction and the heat losses by the electric heating, an almost isothermal behavior of the microchannel reactor was observed. In the less favorable case, with a $460 \mathrm{mg}$ catalyst load, $\Delta \mathrm{T}_{\mathrm{MSR}}$ was about $8 \mathrm{~K}$ and $\Delta \mathrm{T}_{\mathrm{COMB}}$ was about $16 \mathrm{~K}$. This confirmed good coupling of the methanol steam reforming and the methanol combustion.

Keywords: $\mathrm{H}_{2}$ production; microreactor; integration

\section{Introduction}

Hydrogen is a clean fuel that produces only water, electricity, and heat when it is consumed in a fuel cell. This fuel has the potential for use in a broad range of applications, across virtually all sectors-transportation, commercial, industrial, residential, and it is portable. Therefore, hydrogen and fuel cells can play an important role in decarbonization strategy for a sustainable energy future.

The production of hydrogen can be obtained by catalytic steam reforming of hydrocarbons such as methane, naphtha, methanol, ethanol, etc. [1]. Among the hydrocarbons considered in hydrogen production onboard, methanol has received much attention. The main advantage of methanol steam reforming (MSR) is the low reforming temperature (473-573 K) leading to a low carbon monoxide (CO) concentration in the product gases $[1,2]$. The MSR catalysts have to be efficient and highly selective toward $\mathrm{CO}_{2}$ over $\mathrm{CO}$, which is important because the CO poisons the anode of the fuel cell [3].

In the reforming reactions, efficient heat transfer is important because MSR is a highly endothermic reaction $(\Delta \mathrm{H}=49.5 \mathrm{KJ} / \mathrm{mol})$. Metallic microreactors, microstructured reactors with channels with a dimension below $1 \mathrm{~mm}$, offer potential advantages of improved heat and mass transfer, more precise control of reaction temperature within flammable regions leading to reduced hot spots, and higher surface area to volume ratio of the microchannels $[2,4]$. Furthermore, these microdevices can be very compact and easily 
integrated with fuel stacks to generate power onboard. There are a large number of studies on the development of microreactors for hydrogen production [5-7].

Since MSR is an endothermic reaction, a heat source is necessary to maintain the reaction temperature. On an industrial scale, reforming reactors consist of a bundle of tubes that are externally heated by combustion. However, for more compact systems this solution is less viable because heat losses, integration and physical space become critical factors. Thanks to microreactors, a new way is opened to integrate the reforming and combustion reaction in the same reactor.

Microchannel reactors are gaining great importance due to the fact that they have great advantages such as an increase in the surface/volume ratio, a reduction in the reactor volume, an improvement in mass and heat transfer properties, and consequently a better control of the reactor temperature by reducing hot spots [8].

Regarding the heat losses, those produced by conduction through the tubes and connections of the microdevices can be important $[9,10]$. Although the size of the reactor can be remarkably reduced, pipes connecting the reactor to other components cannot be reduced in the same proportion. One way to minimize these heat losses is to achieve high levels of thermal integration and thus obtain high energy efficiencies. Sufficient energy must be supplied to the system to evaporate the feed mixture and maintain the desired temperature for the methanol reforming reaction [11-15]. The way of supplying the necessary heat to the reactor plays a very important role, an electrical supply being most used at the laboratory scale. In most cases, the reformer is heated externally by wrapping an electric heater around the reformer wall [2,16] or internally by placing a heat source inside the reformer [17].

However, the use of electrical power is not feasible on an industrial scale due to its high cost, so the combustion of a fuel is often used [18]. Thanks to the integration of an exothermic reaction in adjacent channels to those of the reforming, the efficiency of the system is improved and the design of the system is simplified. The thermal coupling becomes an important part of developing compact units for process intensification using microchannel reactors. Furthermore, the microreactor design and operating conditions have a great importance for optimal thermal management. It is therefore of great interest to determine the optimal conditions to provide design guidelines for hydrogen production using coupled combustion-reforming catalytic microreactors.

Among the possible fuels for the combustion reaction, one of the most interesting options is hydrogen from the rejection of the fuel cell. Fuel cells do not usually consume all the hydrogen fed from the reformer, normally around $20 \%$ leaves the fuel cell without being converted, its recovery being possible for feeding as fuel to provide the necessary energy in the reforming process. However, most microchannel reactor integration studies use the same methanol as fuel. Reuse et al. [19] were among the first to successfully combine both, the endothermic reforming reaction and the exothermic combustion of methanol. The improved isothermicity offers better performance as compared to other conventional reactors [20]. In our case, the fuel chosen is methanol, the same molecule that is being reformed, which facilitates the experimental device. This strategy, previously used by numerous authors $[7,12,13,21]$, does not pretend to question the undeniable interest of using $\mathrm{H}_{2}$ from the cathodic rejection of the fuel cell as a more efficient alternative. However, in our opinion, the results of the integration of both reactions would be valid for the use of $\mathrm{H}_{2}$ as fuel.

The factors affecting the overall performance in the integration of catalytic combustion in a reformer can be summarized as follows: the material and thickness of the channel walls, the size of the channels, the geometry of the reactor, the heat losses, the type of fuel fed, the S/C ratio, the reactor length, and the type and amount of catalyst coating [21-25].

The influence of heat losses on the performance of the microreformers has rarely been addressed in the literature. Holladay et al. observed that for a small microreformer when the output is only $100 \mathrm{~mW}_{\mathrm{el}}$ the efficiency was $4.5 \%$ due to the strong influence of heat losses $[10,26]$. Shah and Besser studied the heat losses of a silicon microreactor for methanol 
reforming that produced $0.65 \mathrm{~W}_{\mathrm{el}}[27,28]$. The total energy requirement was $0.13 \mathrm{~W}(10 \%$ of the total) for the MSR, $0.20 \mathrm{~W}$ (15\% of the total) for the vaporization of the reagents and $1.0 \mathrm{~W}$ to compensate for heat losses; that is, up to $75 \%$ of the energy consumed is lost in dissipations. According to these authors, the heat losses were due to natural convection, which was at least three times greater than the radiation losses. It should be noted that conduction heat losses through the tubes were not considered by these authors. Pan and Wang [5] performed a scale-up of a combustion-coupled reformer reactor. In the larger scale reactor, they found that heat losses were much lower than when working on a smaller scale and that less power was needed to heat the reforming chambers. Uriz et al. [9] observed by CFD simulation that under real operating conditions the energy demand can be up to nine times higher than just the reforming reaction due to heat losses.

Another factor to take into account is the relative architecture of the reforming and combustion flows [29]. There are several strategies to dispose of the flows of both reactions, the most common are parallel, opposite and crossed flow. From the point of view of isothermicity, the parallel flow is the most convenient and the opposite flow is the least suitable. However, when designing a microchannel block, cross-flow feeding offers the great advantage of facilitating the introduction of flows, simplifying the design of the system and the necessary connections.

In our previous work, we designed a methanol steam microreformer $\left(8 \mathrm{~cm}^{3}\right)$ which was able to produce $170 \mathrm{LH}_{2} / \mathrm{h}$, but the heat was supplied electrically [2]. In the present work, we manufactured a metallic microchannel block coupling the exothermic and endothermic process. The $\mathrm{Pd} / \mathrm{ZnO}$ catalyst for MSR and $\mathrm{Pd} / \mathrm{Al}_{2} \mathrm{O}_{3}$ for combustion were selected. The $\mathrm{Pd} / \mathrm{ZnO}$ type catalysts exhibited comparable MSR activity to the $\mathrm{Cu}$ based ones (the most commonly used for MSR) with extremely low CO selectivity and higher thermal stability [30]. On the other hand, the most used catalysts for combustion are $\mathrm{Pt}$, Pd or Rh noble metals dispersed on supports such as $\mathrm{Al}_{2} \mathrm{O}_{3}, \mathrm{SiO}_{2}$ or $\mathrm{TiO}_{2}$ [31]. The high activity of palladium and the high specific surface area of alumina help a better dispersion of the metal. In turn, the price of $\mathrm{Pd}$ is lower than that of $\mathrm{Pt}$, which would lead to a cheaper industrial catalyst. Different experiments were carried out to evaluate the heat loss from the microchannel block, the endothermic heat requirement of the reforming reaction and the exothermic heat produced by the methanol combustion reaction. In this way, the total power requirement for continuous operation of the reformer has been estimated.

\section{Materials and Methods}

The metallic microchannel block was manufactured using iron base alloy (Fecralloy, Goodfellow, Wrexham, UK). The microchannels (depth: $700 \mu \mathrm{m}$; width: $700 \mu \mathrm{m}$; length: $20 \mathrm{~mm}$; number of channels per plate: 10) were manufactured by micromilling on $20 \mathrm{~mm} \times 20 \mathrm{~mm} \times 1 \mathrm{~mm}$ plates. The machined plates were stacked, rotated $90^{\circ}$ each one and were welded by diffusion welding using a nickel-based metallic glass interlayer with a composition of Ni-14B-7Si (wt.\%, Goodfellow) [32]. This interlayer was an amorphous melt spun foil with a thickness of $25 \mu \mathrm{m}$. The bonding process was performed in vacuum using a test machine developed by Microtest at $850{ }^{\circ} \mathrm{C}$ with an applied force of $2.8 \mathrm{kN}$ ( $\sim 7 \mathrm{MPa})$ for $40 \mathrm{~min}$.

Final blocks designed to combine combustion and MSR were composed of 10 plates for MSR welded intercalated by 10 additional plates for combustion, resulting in $100 \mathrm{mi}-$ crochannels in each direction (see Figure 1). This architecture of crossed flows, despite not being the most efficient from the point of view of thermal integration [18], was the one that allowed a simpler flow connection (Figure 2c). Homemade parallel channel monoliths ( $\mathrm{L}=3 \mathrm{~cm}$, diameter of $1.6 \mathrm{~cm}, 1100 \mathrm{cpsi}$ ) consisting of $50 \mu \mathrm{m}$ Fecralloy sheets (Goodfellow) corrugated using rollers producing channel sizes similar to the microchannel block were manufactured (see Figure 1). These monoliths were used to optimize the washcoating variables used in the coating of the microchannel blocks and also to study the methanol combustion reaction. Monoliths were made by rolling alternate flat and corrugated sheets around a spindle. In order to improve the interaction between the catalyst coating and the 
metallic support, the microchannel blocks and monoliths were pretreated in air for $22 \mathrm{~h}$ at $1173 \mathrm{~K}$ generating a 5-6 $\mu \mathrm{m}$ thick and rough alumina layer.

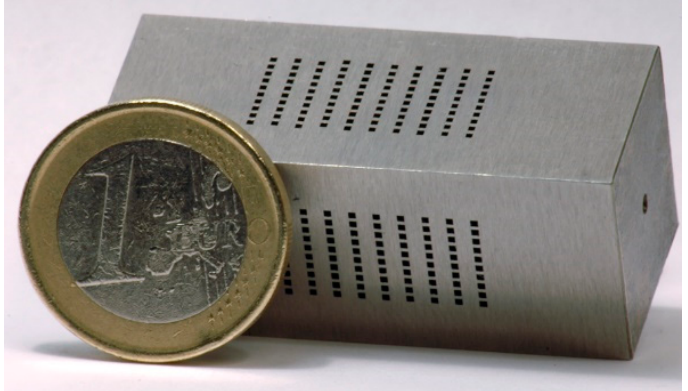

(a)

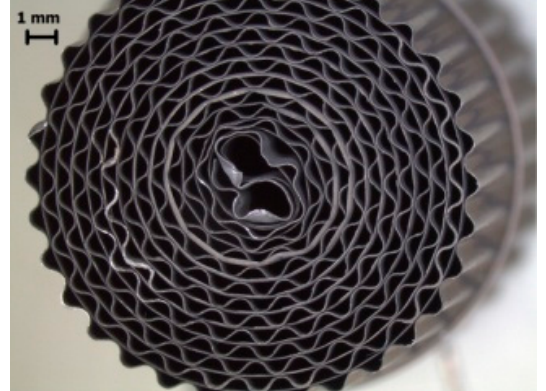

(b)

Figure 1. Structured support images: (a) microchannel block; (b) microchannel monolith.

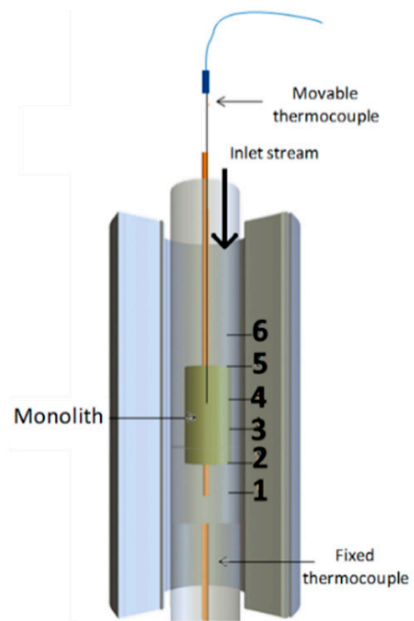

(a)

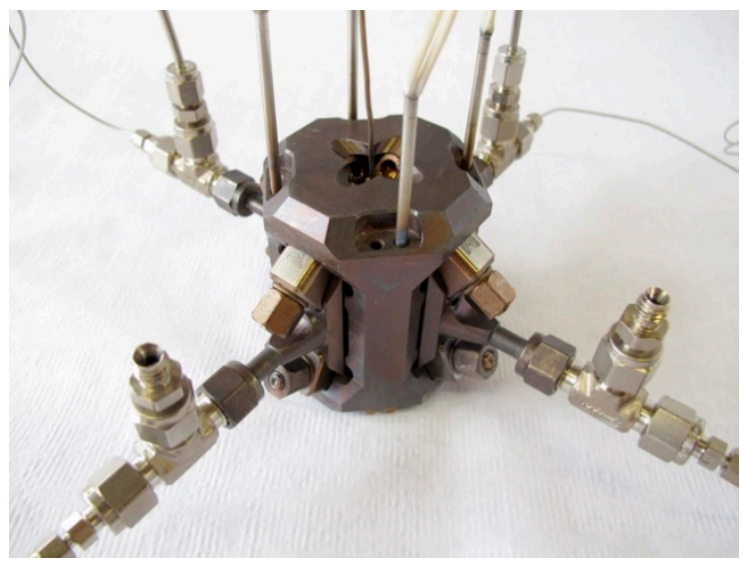

(c)

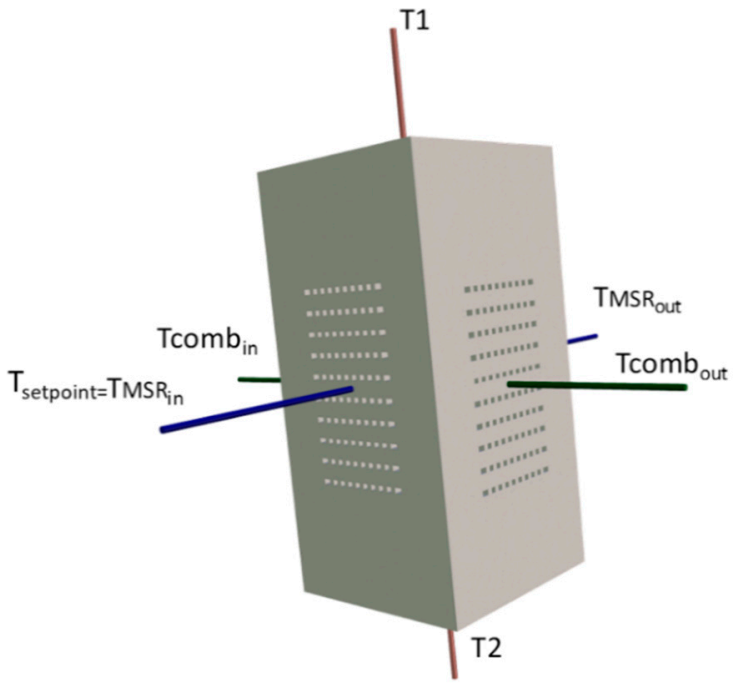

(b)

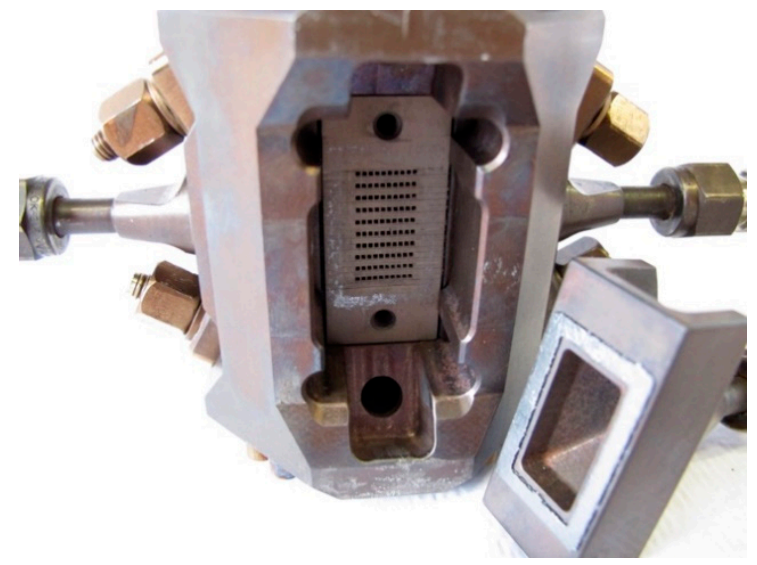

(d)

Figure 2. Thermocouple arrangement: (a) for microchannel monolith (b) for microchannel block; (c,d) microchannel block housing including flow headers, thermocouples, and heating cartridges.

The washcoating method was used to deposit both catalysts on the corresponding block microchannels. The catalyst slurries used were: 
- Combustion catalyst slurry: first, $\mathrm{Pd} / \mathrm{Al}_{2} \mathrm{O}_{3}$ catalyst was prepared via incipient wetness impregnation of $\mathrm{Al}_{2} \mathrm{O}_{3}$ (Spheralite) with the adequate amount of $\mathrm{PdNO}_{3}$ (Johnson Matthey) to obtain $0.25-1 \% \mathrm{Pd}$ in the catalyst, dried and calcined at $773 \mathrm{~K}$ for $2 \mathrm{~h}$. For this catalyst slurry preparation, a preliminary study, not shown here, on the variables that control the washcoating process was carried out [33]. The coating characteristics, specific load, homogeneity and adhesion were the control variables used to choose the best recipe (see Table 1).

- $\quad$ MSR catalyst slurry: first, $\mathrm{ZnO}$ was synthesized by thermal decomposition of $\mathrm{Zn}$ oxalate prepared by precipitation of $\mathrm{ZnC}_{2} \mathrm{O}_{4}$ from a $6 \mathrm{M}$ nitrate solution by drop wise addition at $313 \mathrm{~K}$ of a $1.7 \mathrm{M}$ oxalic acid solution [2]. For the catalyst slurry preparation, a new strategy developed in our previous work [34] was used, preparing the suspension in water with the catalyst precursors (see Table 1). In this way, the catalyst preparation and the substrate coating were carried out in a single step producing a much more active and stable structured catalyst showing excellent adherence to the substrate.

Table 1. Catalyst slurry formulation.

\begin{tabular}{|c|c|c|}
\hline Compounds & MSR Catalyst Slurry (wt.\%) & Combustion Catalyst Slurry (wt.\%) \\
\hline $\mathrm{ZnO}$ & 22.5 & - \\
\hline $\mathrm{PdNO}_{3}$ (Johson Matthey) & 1.20 & - \\
\hline $\mathrm{Pd} / \mathrm{Al}_{2} \mathrm{O}_{3}$ & - & 16.0 \\
\hline Colloidal $\mathrm{Al}_{2} \mathrm{O}_{3}$ (Nyacol AL20) & - & 2.00 \\
\hline Colloidal ZnO (Nyacol DP5370) & 2.50 & - \\
\hline Polyvinyl alcohol & - & 2.00 \\
\hline $\mathrm{H}_{2} \mathrm{O}$ & 73.8 & 80.0 \\
\hline $\mathrm{pH}$ & 4.3 & 4.1 \\
\hline
\end{tabular}

To allow the correct covering of only the walls of the corresponding microchannels, the pretreated microchannel blocks were previously covered with masking tape to protect the whole exterior surface except the entry and exit of the microchannels to be coated. The combustion catalyst was coated first as this requires double calcination which would further harm the MSR catalyst. The hanging blocks with the channels to be coated were oriented perpendicular to the surface of the slurry, dipped into the catalyst slurry for $60 \mathrm{~s}$, and withdrawn at a constant speed of $3 \mathrm{~cm} \cdot \mathrm{min}^{-1}$. Then, the elimination of the slurry excess was made by blowing compressed air until all the channels were liquid free to prevent plugging [35]. The coating was repeated several times with an intermediate drying step at $393 \mathrm{~K}$ for $30 \mathrm{~min}$ between coatings until the desired combustion catalyst load was achieved $(\approx 140 \mathrm{mg})$. Calcination of the coated block was done at $723 \mathrm{~K}$ for $2 \mathrm{~h}$. After that, the blocks were dipped into the MSR catalyst slurry using the same withdrawing process, slurry excess elimination technique and drying steps until the desired MSR catalyst load (140, 245 and $417 \mathrm{mg}$ ) was obtained. Finally, the blocks were calcined at $623 \mathrm{~K}$ for $3 \mathrm{~h}$.

The combustion reaction was also studied on microchannel monoliths. The monoliths were coated by the same method with combustion catalyst slurry (see Table 1) except that slurry excess elimination was made by centrifugation ( $1 \mathrm{~min}, 400 \mathrm{rpm})$. Finally, calcination of the coated microchannel monoliths was carried out at $723 \mathrm{~K}$ for $2 \mathrm{~h}$.

The textural properties of the slurried catalyst were determined by nitrogen adsorption using a Micromeritics ASAP 2020. X-ray diffraction (XRD) analysis was performed on a Bruker D8 Advance Vårio. Diffraction patterns were recorded with $\mathrm{Cu} \mathrm{K} \alpha$ radiation over a $0-60^{\circ} 2 \theta$ using a position sensitive detector with a step size of $0.05^{\circ}$ and a step time of $5 \mathrm{~s}$. The adherence of the catalytic layer deposited was evaluated by the weight loss caused by the exposition of the sample to ultrasounds. The samples immersed in petroleum ether were submitted to an ultrasonic treatment for $30 \mathrm{~min}$ at room temperature. After that, the samples were dried and calcined. The weight loss was determined by the weight 
difference of the samples before and after the ultrasonic test. The results are presented as the percentage of the original coating remaining after the ultrasound treatment.

Catalytic tests of the microchannel block were carried out at atmospheric pressure using a Computerized Microactivity Reference Catalytic Reactor from PID Eng \&Tech used as a mother reactor to house the reactor containing the microchannel block in its hot box. In this way, the mother reactor provides flow, pressure and temperature control systems, and connections for online analysis. The temperature of the microchannel block was monitored with 6 thermocouples (see Figure 2): 4 in the same horizontal plane, 2 of them at the microchannel entry and the other 2 at the microchannel outlet, and 2 additional thermocouples at the upper and bottom sides of the block. The thermocouple of the MSR inlet was used to set the temperature controller set point. The microchannel block was placed in the center of a housing (Figure $2 b, c$ ) that included the headers with their corresponding sealing gaskets that ensured the correct distribution of the inlet and outlet flow of the microchannels, the six thermocouples and four electrical cartridges. These cartridges allowed the reduction pretreatment to be carried out and could provide the necessary heat during the reaction acting alone or in combination with the methanol combustion reaction. Before introducing the casing with the block and all the accessories described in the hot box of the mother reactor, a thick layer of about $20 \mathrm{~mm}$ of thermal insulation made of mineral wool was added (Figure S1). For methanol combustion, methanol/air (5/95) was fed using a Bronkhorst CEM-System coupled to a cascade flow and temperature controller developed in collaboration with PI\&D (flow rate was varied between $400-1600 \mathrm{NmL} \mathrm{min}{ }^{-1}$ ). The main temperature controller acts on a slave methanol flow controller which in turn acts on another slave air flow controller which keeps the methanol/air ratio constant equal to $5 / 95$. The methanol conversion was calculated by measuring the production of $\mathrm{CO}_{2}$ by an on-line IR detector (VAISALA).

Methanol combustion in the microchannel monolith was also performed in the hot box of the Microactivity apparatus (PID Eng \& Tech) using a conventional $17 \mathrm{~mm}$ internal diameter tubular reactor and the same feeding and analysis lines indicated in the previous paragraph. The axial temperature profile was measured by fixing the oven power to ensure a temperature of $623 \mathrm{~K}$ in the center of the monolith and sliding the reading thermocouple from $1 \mathrm{~cm}$ before to $1 \mathrm{~cm}$ after the microchannel monolith (see Figure 2d).

For the methanol steam reforming, the catalyst was reduced at $773 \mathrm{~K}$ for $2 \mathrm{~h}$, under a flow of $50 \mathrm{NmL} \min ^{-1}$ of $10 \% \mathrm{H}_{2}$ in $\mathrm{N}_{2}$. This reduction temperature was selected to ensure the formation of PdZn alloy, the active phase for MSR with low CO selectivity [36]. The reaction was carried out at $623 \mathrm{~K}$ with a steam-to-carbon molar ratio (S/C) of 1.5, using an HPLC (high-performance liquid chromatography) pump to feed the methanol-water mixture. Some $45 \% \mathrm{~N}_{2}$ was added to facilitate the evaporation of the methanol/water and to be used as the internal standard for GC. Gaseous products were taken out through a thermostatic line at $473 \mathrm{~K}$ and analyzed with a 7890A Agilent GC, using a TDC to analyze $\mathrm{H}_{2}, \mathrm{CO}, \mathrm{CO}_{2}, \mathrm{~N}_{2}, \mathrm{H}_{2} \mathrm{O}$ and $\mathrm{CH}_{3} \mathrm{OH}$. Methanol conversion is defined as the ratio between converted methanol and the methanol fed,

$$
X=\frac{\left(n_{\text {Methanol, in }}-n_{\text {Methanol, out }}\right)}{n_{\text {Methanol, in }}}
$$

$\mathrm{CO}$ and $\mathrm{CO}_{2}$ selectivity $(\mathrm{Si})$ is defined as the ratio between produced $\mathrm{CO}$ or $\mathrm{CO}_{2}(\mathrm{ni})$ and the total carbon-containing species produced $\left(n_{\mathrm{CO}}+n_{\mathrm{CO}_{2}}\right)$,

$$
S_{i}=\frac{n_{i}}{\left(n_{\mathrm{CO}}+n_{\mathrm{CO}_{2}}\right)}
$$

\section{Results}

\subsection{Microchannel Block and Monolith Preparation}

Microchannel coatings should be thin, which limits the methods that can be applied to coat structures. In all of these applications, an appropriate amount of catalytic material 
has to be distributed along the reactor channels. Therefore, the washcoating method was selected as the most favorable, due to its versatility that it is well suited to the geometry of our substrates, as we observed in our previous works [2,4,33]. A series of blocks and monoliths were prepared, and the washcoating method produced adherent $(>90 \%)$ and homogeneous coatings without plugging the microchannels (see Figure 3).

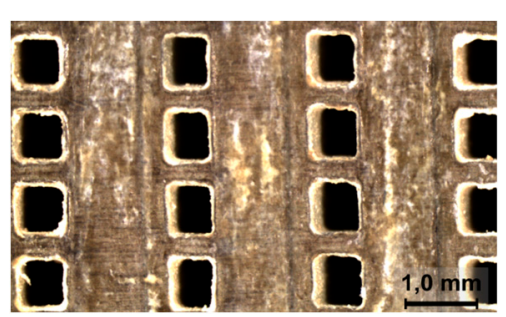

(a)

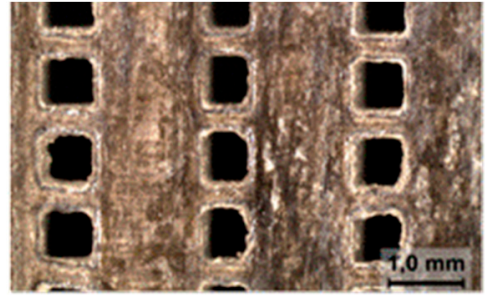

(b)

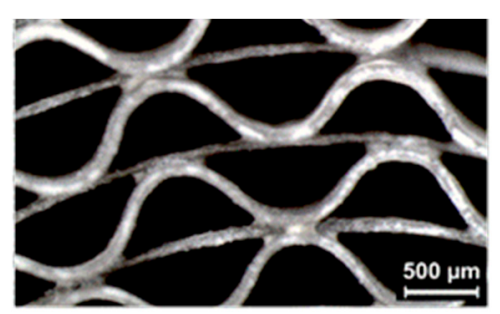

(c)

Figure 3. Image of coated structured substrates: (a) MSR catalyst coating on microchannel block; (b) combustion catalyst coating on microchannel block; (c) combustion catalyst coating on microchannel monolith.

Table 2 shows the textural properties of the powder catalysts obtained after drying and calcination of the slurry, called slurried catalysts. The $\mathrm{Pd} / \mathrm{ZnO}$ catalyst presented a higher specific surface area than the parent $\mathrm{ZnO}$ due to a change in particle size during the preparation of the catalyst slurry for washcoating [36]. When the $\mathrm{ZnO}$ support was exposed to an acidic solution, some $\mathrm{ZnO}$ could have leached in the form of $\mathrm{Zn}^{2+}$ ions and reprecipitated onto the $\mathrm{ZnO}$ matrix, modifying the BET surface area. The $\mathrm{Pd} / \mathrm{Al}_{2} \mathrm{O}_{3}$ catalyst presented a lower specific surface area than the commercial support due to the alumina colloid incorporated in the slurry formulation.

Table 2. Textural properties.

\begin{tabular}{cccc}
\hline Samples & $\mathbf{S}_{\text {BET }}\left(\mathbf{m}^{2} / \mathbf{g}\right)$ & $\mathbf{V}_{\text {pore }}\left(\mathbf{c m}^{\mathbf{3}} \mathbf{g}\right)$ & $\mathbf{D}_{\text {pore }}(\mathbf{n m})$ \\
\hline $\mathrm{ZnO}$ & 39 & 0.24 & 24 \\
Colloidal ZnO & 55 & 0.13 & 10 \\
$2.5 \% \mathrm{Zd} / \mathrm{ZnO}$ (slurried catalyst) & 50 & 0.25 & 19 \\
$\mathrm{Al}_{2} \mathrm{O}_{3}$ & 240 & 0.40 & 70 \\
${\mathrm{Colloidal} \mathrm{Al}_{2} \mathrm{O}_{3}}_{1 \% \mathrm{Pd} / \mathrm{Al}_{2} \mathrm{O}_{3} \text { (slurried catalyst) }}^{160}$ & 234 & - & - \\
\hline
\end{tabular}

Figure 4 shows the wide-angle diffraction pattern of the synthesized catalyst. The XRD patterns of $\mathrm{ZnO}$ and $\mathrm{Pd} / \mathrm{ZnO}$ showed peaks indexed by a hexagonal wurtzite phase of $\mathrm{ZnO}$ (JCPDS card no. 36-1451) and the high-temperature reduction led to 1:1 PdZn alloy formation at $41.5^{\circ}$ (JCPDS no. 87-0639) [36]. The combustion catalyst showed characteristic reflections of $\mathrm{Al}_{2} \mathrm{O}_{3}$ at values $2 \theta=19.4,32.0,37.7,45.9$ and 67.0 (PDF 79-1558) [37], and the reflections at $2 \theta=33.8$ and $54.7^{\circ}$ (PDF 41-1107) were attributed to PdO [37]. The impregnation with $\mathrm{Pd}$ and the calcination did not modify the crystalline properties of the support. 


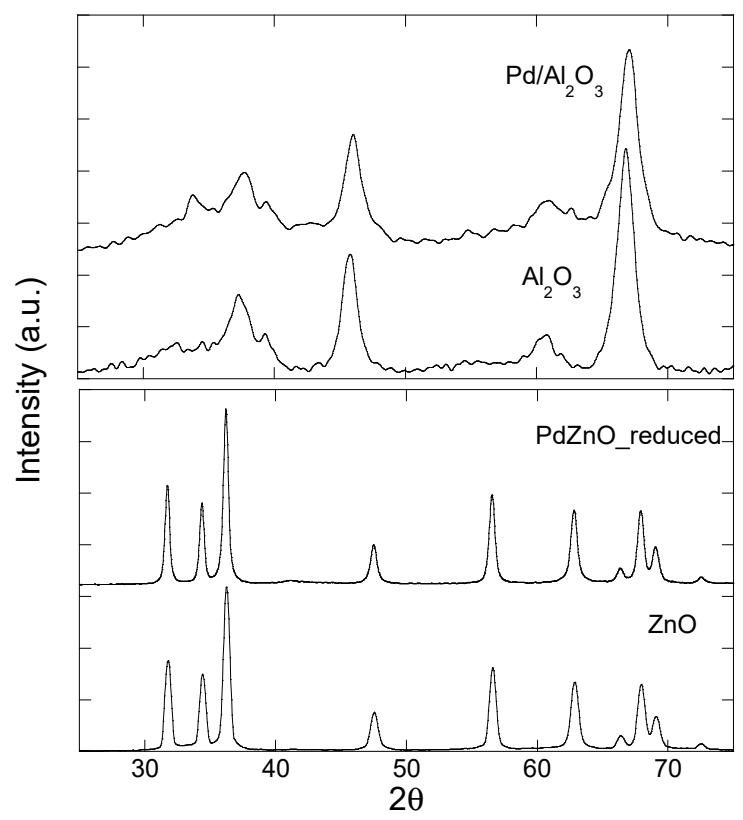

Figure 4. XRD of the supports and catalyst.

\subsection{MRS and Combustion Reaction in the Microchannel Block}

The experiments carried out are indicated below, grouped by series with the reference assigned to them and which are indicated in the text (Table 3):

- Study of heat loss:

For this study, the supplied electric power and temperature at different points were analyzed for the washcoated microchannel block at $623 \mathrm{~K}$ with different feed flows: $206 \mathrm{~mL} / \mathrm{min} \mathrm{H}_{2} \mathrm{O} / \mathrm{MeOH} / \mathrm{N}_{2}$, equivalent $\mathrm{N}_{2}$ flow and no flow throughout the reactor (HL-1).

- The influence of the reaction conditions on heat losses: temperature (HL-2), catalyst loading (HL-3), and reforming flow(HL-4).

- Study of combustion and reforming coupled on the block:

In order to study whether the combustion reaction was carried out homogeneously along the microchannels, this reaction was previously studied on washcoated monoliths. The experiments were carried out modifying variables such as feed flow, catalyst load and Pd content of the catalyst, analyzing the combustion conversion and temperature profiles for each case (experiments not included in the table below).

A series of experiments was carried out to evaluate in which conditions the dissipations were compensated with electrical power, and the reforming and decomposition reactions of methanol with the combustion reaction (CRC-1).

- Finally, in the next experiments, the heat losses were compensated with the electrical power, and the integration between the two reactions was studied varying the MSR reaction temperature (CRC-2), the MSR catalyst amount (CRC-3) and the space velocity (CRC-4). 
Table 3. The list of experiments carried out with microchannel blocks.

\begin{tabular}{|c|c|c|c|c|c|c|c|}
\hline \multirow{2}{*}{\multicolumn{2}{|c|}{ Experiment Reference }} & \multicolumn{2}{|c|}{ Heating System } & \multirow{2}{*}{$\begin{array}{l}\text { MSR Catalyst } \\
(\mathrm{mg})\end{array}$} & \multirow{2}{*}{$\begin{array}{c}\text { Comb. } \\
\text { Catalyst (mg) }\end{array}$} & \multirow{2}{*}{$\mathrm{T}_{\text {Refom. }}(\mathrm{K})$} & \multirow{2}{*}{$\begin{array}{c}\text { Space Velocity } \\
\left(\mathrm{mmol}_{\mathrm{MeOH}} / \mathrm{min} \bullet_{\mathrm{Cat}}\right)\end{array}$} \\
\hline & & Electrical (\%) & Comb. (\%) & & & & \\
\hline \multirow{4}{*}{ Heat loss } & HL-1 & 100 & 0 & 245 & 140 & 623 & $\begin{array}{c}15 \\
\text { equivalent } \mathrm{N}_{2} \text { flow } \\
0\end{array}$ \\
\hline & HL-2 & 100 & 0 & 245 & 140 & $598 / 623 / 648$ & 15 \\
\hline & HL-3 & 100 & 0 & $140 / 245 / 471$ & 140 & 623 & 15 \\
\hline & HL-4 & 100 & 0 & 245 & 140 & 623 & $7 / 15 / 30 / 45 / 60$ \\
\hline \multirow{8}{*}{$\begin{array}{c}\text { Comb. } \\
\text { Reform. } \\
\text { Coupling }\end{array}$} & \multirow{5}{*}{ CRC-1 } & 0 & 100 & \multirow{5}{*}{245} & \multirow{5}{*}{140} & \multirow{5}{*}{623} & \multirow{5}{*}{15} \\
\hline & & 50 & 50 & & & & \\
\hline & & 75 & 25 & & & & \\
\hline & & 85 & 15 & & & & \\
\hline & & 100 & 0 & & & & \\
\hline & CRC-2 & 15 & 85 & 245 & 140 & $598 / 623 / 648$ & 15 \\
\hline & CRC-3 & 15 & 85 & $140 / 245 / 471$ & 140 & 623 & 15 \\
\hline & CRC-4 & 15 & 85 & 245 & 140 & 623 & $7 / 15 / 30 / 45 / 60$ \\
\hline
\end{tabular}

\subsubsection{Heat Loss on the Microchannel Block}

Figure 5 (experiments HL-1) shows the heat input to the integrated microchannel reactor during different operation conditions calculated as the electric power at a steady state required to stabilize the block at the chosen setpoint temperature, $623 \mathrm{~K}$. In experiment 1, the microchannel block (245 $\mathrm{mg}$ of MSR catalyst and $140 \mathrm{mg}$ of combustion catalyst) was electrically heated, maintaining the reaction temperature at $623 \mathrm{~K}$ using $15 \mathrm{mmol}_{\mathrm{MeOH}} / \mathrm{min} \cdot \mathrm{g}_{\mathrm{Cat}}$ as feed. In these reaction conditions, the methanol steam reforming conversion of the reformer was about $98 \%$, producing $60 \mathrm{~L}_{\mathrm{H} 2} / \mathrm{h} \cdot \mathrm{g}_{\text {cat }}$ with very low CO selectivity $(\approx 5 \%)$, and the consumed heat measured was $47.4 \mathrm{~W}$. The energy required to compensate the endothermic reactions $\left(Q_{\text {React }}=8.76 \mathrm{~W}\right)$ was quantified supposing that only the methanol reforming and methanol decomposition took place using $\mathrm{PdZnO}$ catalyst $[38,39]$. Comparing the results, it could be seen that the power provided to keep the reactor temperature at $623 \mathrm{~K}$ was much higher than that required for the methanol reforming reaction. The difference was due to the sensible heat necessary to heat up the feed and the heat dissipated to the hot box in which the reactor was located.

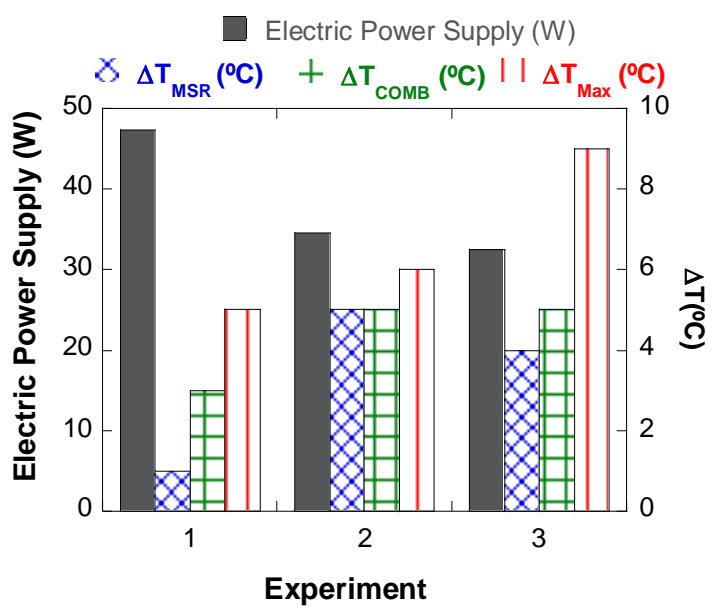

Figure 5. Power supply and temperature differences concerning the setpoint $(623 \mathrm{~K})$ in different experiments: reforming feed of $206 \mathrm{~mL} / \mathrm{min} \mathrm{H}_{2} \mathrm{O} / \mathrm{MeOH} / \mathrm{N}_{2}$ (1), equivalent $\mathrm{N}_{2}$ flow (2) or no flow throughout the reactor (3) $\left(\Delta \mathrm{T}_{\text {MSR }}=\mathrm{T}_{\text {MSRin }}-\mathrm{T}_{\text {MSRout }}, \Delta \mathrm{T}_{\mathrm{COMB}}=\mathrm{T}_{\text {COMBin }}-\mathrm{T}_{\text {COMBout }}, \Delta \mathrm{T}_{\text {Max }}=\right.$ the maximum temperature difference observed between the 6 temperature points).

To differentiate between the heat dissipated by the microchannel reactor to the hot box and the sensible heat required to bring the feed at the reaction setpoint temperature, experiments replacing the reforming feed with nitrogen (experiment 2 ) and without feeding 
(experiment 3) were carried out (see Figure 5). Less power was required to maintain the microchannel block at the desired temperature when the reforming feed stream was replaced by nitrogen. The difference in power between the two experiments $(\approx 8.34 \mathrm{~W})$ matched reasonably the calculated reaction enthalpy. On the other hand, when the block was heated without any gas feed, it could be seen that the power to reach the temperature setpoint $(623 \mathrm{~K})$ decreased. Therefore, the sensible heat necessary to heat up the gas stream was $2.1 \mathrm{~W}$ at $623 \mathrm{~K}$.

The smallest temperature difference in the block $\left(\Delta \mathrm{T}_{\max }\right)$ was obtained when a nitrogen flow was introduced (Figure 5), because the feed helped to homogenize the temperature in the block without heat consumption due to MSR reaction.

On the other hand, the influence of the reaction conditions (temperature (HL-2), catalyst loading (HL-3), and reforming flow (HL-4)) on the system was studied by heating electrically (Figure 6). At the scale studied here, the heat loss increased slightly with the steam reforming temperature (Figure $6 \mathrm{a}$ ). At the studied conditions, increasing temperature from 598 to $648 \mathrm{~K}$, the heat loss increased from 23.5 to $43.4 \mathrm{~W}$. However, the heat losses changed slightly by increasing the catalyst loading and reforming fuel flow rate, being around 32 and $36 \mathrm{~W}$, respectively (Figure $6 \mathrm{~b}, \mathrm{c}$ ).
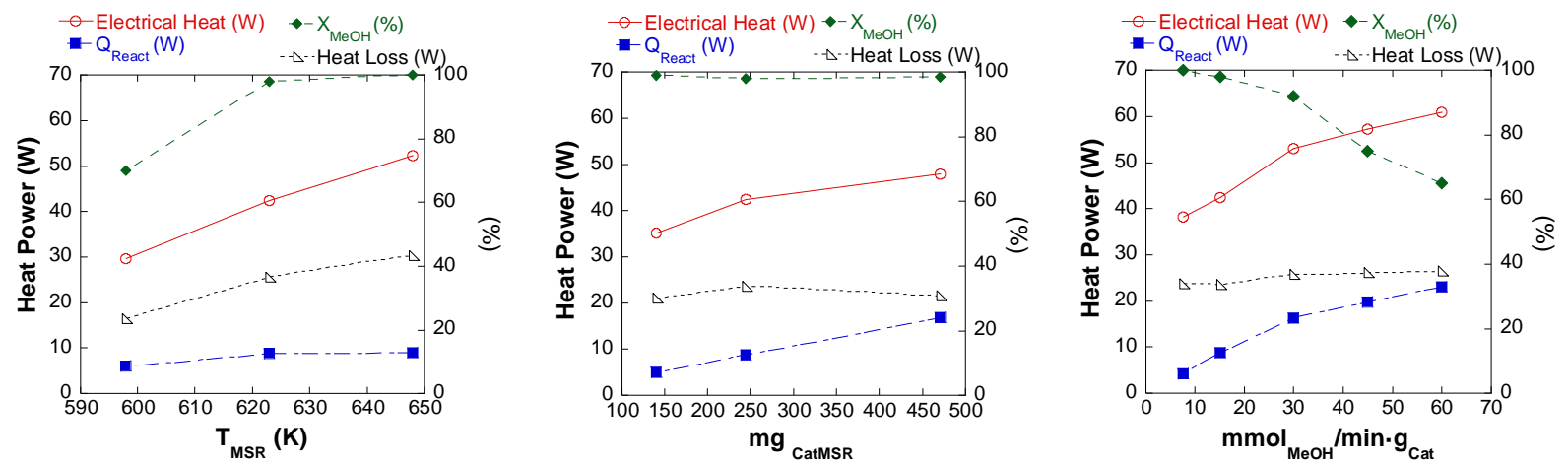

Figure 6. Heat power and methanol conversion variations on microchannel block: (a) the effect of MSR temperature for $245 \mathrm{mg}$ of MSR catalyst at $15 \mathrm{mmol}_{\mathrm{MeOH}} / \mathrm{min} \cdot \mathrm{g}_{\mathrm{Cat}}$; (b) the effect of MSR catalyst amount at $623 \mathrm{~K}$ and $15 \mathrm{mmol}_{\mathrm{MeOH}} / \mathrm{min} \cdot \mathrm{g}_{\mathrm{Cat}} ;$ (c) the effect of space velocity for $245 \mathrm{mg}$ of MSR catalyst at $623 \mathrm{~K}$.

\subsubsection{Combustion Coupled Block (Temperature Profile)}

Methanol Combustion on Microchannel Monolith

First, the combustion reaction was studied on monoliths. These monoliths present channels of similar size to those of the microchannel block and allow the measurement of temperature along the microchannels direction. The experiments were carried out modifying variables such as feed flow, catalyst load and Pd content of the catalyst, analyzing the combustion conversion and temperature profiles for each case.

Figure 7 shows the temperature axial profile of the monolith coated with $200 \mathrm{mg}$ of combustion catalyst at different feed rates. It can be observed that the temperature profile showed a similar shape in all cases, with a sharp temperature increase in the first centimeter, that is, combustion occurred at the entrance to the monolith. The only change when the feed flow increased, that is to say the amount of heat-generated increased, was that the temperature increase was greater. In all cases, 100\% methanol conversion was achieved. 


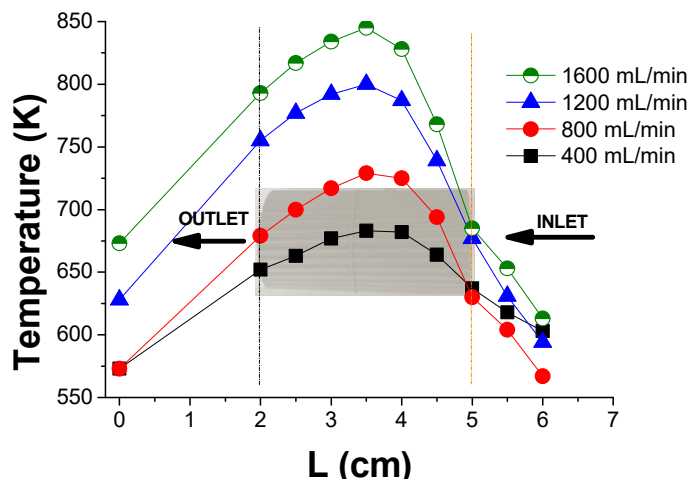

(a)

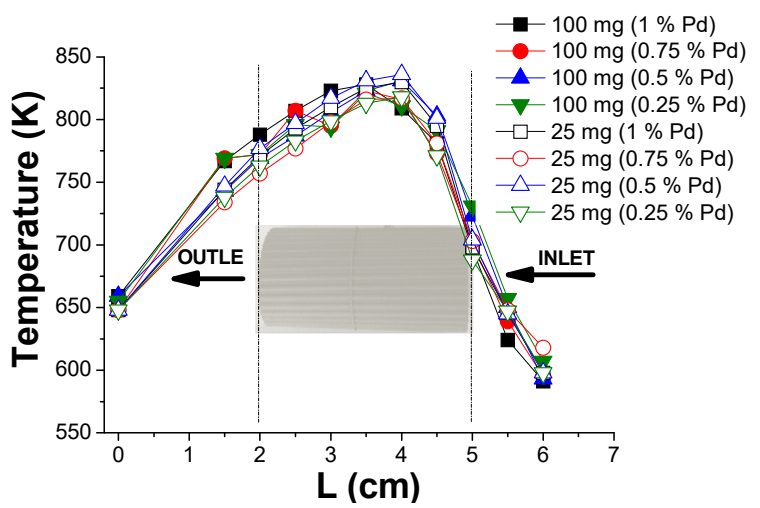

(b)

Figure 7. Temperature profile of monoliths: (a) different flows with monolith loaded with $200 \mathrm{mg}$ and $1 \% \mathrm{Pd}_{/} \mathrm{Al}_{2} \mathrm{O}_{3} ;(\mathbf{b})$ different monoliths with different catalyst loading and Pd content with the same feed flow $1600 \mathrm{~mL} / \mathrm{min}$.

To see if this result was due to an active phase excess, several monoliths were coated with a lower catalyst amount and/or lower Pd content up to the limit that allowed us to guarantee a homogeneous distribution of the catalyst along the channel (Figure 7). The results showed that even decreasing to $25 \mathrm{mg}$ of catalyst with $0.25 \%$ of $\mathrm{Pd}$, it was not possible to smooth the temperature profile, obtaining similar curves and conversions of $100 \%$ in all cases. These results suggest that, at this initial temperature, the combustion catalyst has the only function of producing the ignition of the mixture that probably continues by a homogeneous mechanism.

Methanol Combustion on the Microchannel Block

The maximum temperature difference recorded between two points of the block $\left(\Delta \mathrm{T}_{\max }\right)$ was very small $(\leq 5 \mathrm{~K})$ when the system was heated only electrically (Figure 5$)$. In subsequent experiments, the power of the cartridges was fixed at decreasing values (from 47 to $0 \mathrm{~W}$ ) and the temperature $(623 \mathrm{~K})$ was controlled through the methanol combustion with the cascade flow and temperature controller (experiment CRC-1). As the electrical power was reduced, the combustion power required increased (increased methanol/air flow) producing an increase in combustion entry temperature (Figure 8). This increase could be due to the extremely fast combustion, as had been observed occurring at the microchannels' entry (Figure 7). Nevertheless, the excellent heat conduction characteristics of the microchannel blocks and the consumption of part of the heat by the reforming reaction made the temperature differences (Figure 8) much smaller than those observed in the monolith (Figure 7).

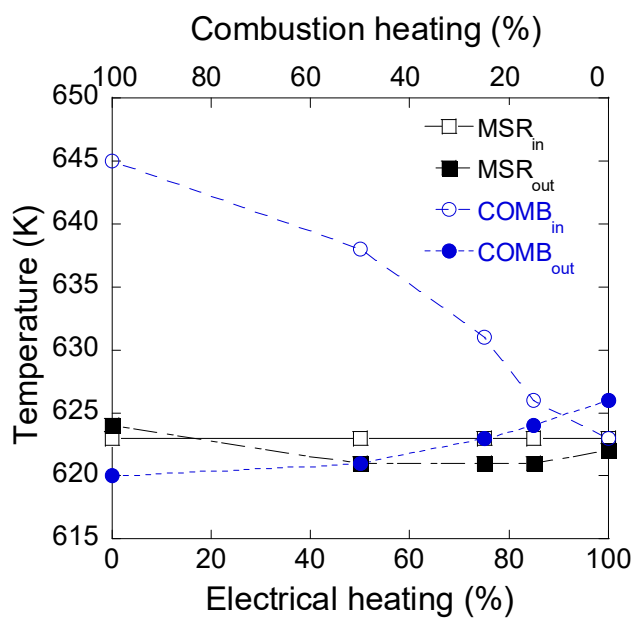

Figure 8. Temperature profile of the block as a function of the electrical power used at $623 \mathrm{~K}$. 
In the next experiments, the heat losses were compensated with the electrical power, and the integration between the two reactions was studied varying the MSR reaction temperature (CRC-2), the MSR catalyst amount (CRC-3) and the space velocity (CRC-4) (Figure 9). To carry out these experiments, the electrical power provided by the electrical cartridges to maintain the reactor at the desired temperature was first measured and the enthalpies of the reforming and decomposition reactions were calculated for the conversion obtained at each temperature. The difference between the total power and the reactions' enthalpies would be the heat dissipated by the reactor. Therefore, in these experiments, a constant electrical power was provided for the heat losses and the rest of the heat necessary to reach the set-point temperature was provided by the methanol combustion.

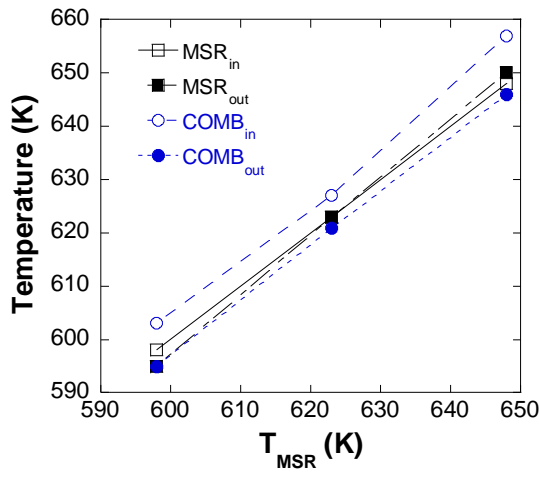

(a)

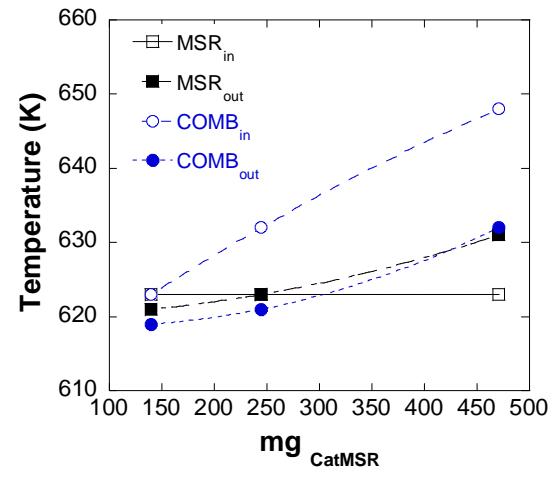

(b)

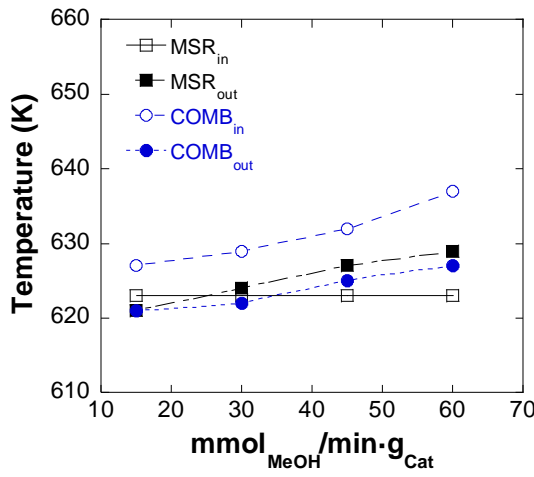

(c)

Figure 9. Temperature profile of the block: (a) the effect of MSR temperature for $245 \mathrm{mg}$ of MSR catalyst at $15 \mathrm{mmol}_{\mathrm{MeOH}} / \mathrm{min} \cdot \mathrm{g}_{\mathrm{Cat}}$; (b) the effect of MSR catalyst amount at $623 \mathrm{~K}$ and $15 \mathrm{mmol} \mathrm{MeOH} / \mathrm{min} \cdot \mathrm{g}_{\mathrm{Cat}}$; (c) the effect of space velocity for $245 \mathrm{mg}$ of MSR catalyst at $623 \mathrm{~K}$.

Figure 9 compares the block temperatures at different reaction temperatures, catalyst loading and space velocity. For these studies, $120 \mathrm{mg}$ of combustion catalyst and $150-460 \mathrm{mg}$ of reforming catalyst were deposited in the microchannel block. It can be seen that the maximum temperature differences observed do not vary significantly in the range of temperatures studied (Figure 9a). On the other side, increasing the catalyst load (Figure $9 b$ ) and the space velocity (Figure 9c), the maximum temperature difference became larger. However, in the less favorable case, with $460 \mathrm{mg}$ catalyst load, $\Delta \mathrm{T}_{\mathrm{MSR}}$ was about $8 \mathrm{~K}$ and $\Delta \mathrm{T}_{\mathrm{COMB}}$ was about $16 \mathrm{~K}$. Therefore, it can be said that a good isothermicity is obtained coupling methanol steam reforming and methanol combustion in the same microchannel block.

\section{Discussion}

With regard to heat losses, in this work it has been observed that the power required to compensate for the reforming reaction is only $15-20 \%$ of the total power needed to keep the block at the desired temperature. The rest of the power was required to compensate for heat losses (Figure 5). This value was very similar to that observed by other authors [10,26-28]. Uriz et al. [9] studied by CFD simulation the effect of heat losses in a methanol microreformer with the same design of the microchannel block and the catalyst used in the present work. They observed that the energy demand was up to nine times higher than just the reforming reaction due to heat losses. These heat loss problems are associated to the laboratory scale, as the outer surface/reaction volume ratio is very large. At an industrial scale, even when using microchannel reactors, this ratio would decrease dramatically, which together with the use of a more efficient insulating casing would lead to a decrease in the relative importance of heat losses with respect to the reaction heat.

In this work, we have designed and fine-tuned an experimental system that has allowed us to estimate the heat losses of the system and compensate for them by means of electric heating cartridges. In this way, the heat necessary for the reforming reaction 
is provided with the combustion of methanol thanks to a temperature and flow cascade controller. Thus, we can study the coupling of both reactions in a block of microchannels without the interference caused by the significant heat losses due to the small size of the laboratory microreactor.

Regarding the temperatures recorded in the microchannel block, it was observed that when the heat necessary for reforming and dissipations was provided solely by electrical power, the temperature difference in the block was small, around $5{ }^{\circ} \mathrm{C}$ (Figure 8 ). It could be said that the block worked in this case in an almost isothermal mode thanks to its high heat conduction. On the other hand, when supplying part of the heat through the methanol combustion reaction, the maximum temperature differences observed became higher (Figure 8). This was because the temperature at the entrance to the combustion side increased significantly: the exothermic combustion reaction occurred rapidly at the channels' entry (Figure 7). As the combustion feed rate increased, the maximum difference in the block temperature increased and occurred at the combustion inlet, keeping the temperatures on the reforming side practically constant. The increase in the air/ $\mathrm{MeOH}$ flow rate and the high activity of the combustion catalyst, caused an increase in the heat generated at the inlet of the block that was dissipated throughout the block (Figure 8). On the other hand, the lowest temperature was recorded at the combustion outlet due to the fact that most of the combustion occurred at the entrance of the channel and the reforming reaction and the heat losses absorbed part of the heat generated in the combustion decreasing thus said temperature.

Regarding the experiments when the reforming reaction was compensated by the combustion reaction and the heat losses by the electric heating, an almost isothermal behavior of the block of microchannels could be seen despite the small-scale problem (Figures 8 and 9). Thanks to the high heat conduction that the microchannel blocks offered, it was possible to work in an almost isothermal mode, a behavior that has been also reported by several authors such as Lo et al. [40]. They recorded the temperatures in a reactor in which they coupled the methanol reforming reactions and methanol combustion. When the two reactions were operating, the different temperatures recorded throughout the reformer showed a variation of $\pm 2 \mathrm{~K}$. Won et al. [12] studied a reactor coated with $\mathrm{Cu} / \mathrm{ZnO} / \mathrm{Al}_{2} \mathrm{O}_{3}$ catalyst for reforming and $\mathrm{Pt} / \mathrm{ZrO}_{2}$ for combustion. The microchannel inlets of the reagents for reforming and combustion were located in opposite positions, generating countercurrent flow. They obtained a temperature difference of $\pm 6 \mathrm{~K}$ controlling the combustion temperature between $483-563 \mathrm{~K}$. Kim [11] studied the methanol reforming reaction coupled to the combustion reaction at a reaction temperature of $523 \mathrm{~K}$, achieving temperature differences between reforming and combustion of $4 \mathrm{~K}$.

On the other hand, other authors have also observed an increase in the temperature differences due to the combustion reaction. The higher temperature at the combustion inlet could be due to the rapid combustion of methanol in the reactor inlet: this heat is consumed by the reforming reaction, and the rest by the heat losses in the system observing a lower temperature at the combustion outlet [12,41]. The presence of hot spots at the combustion inlet becomes more noticeable as the higher combustion feed flow is introduced [11,13], which can cause the catalyst deterioration and the reactor breakage [11].

The reforming reaction coupled to that of combustion in a microchannel reactor has also been studied by means of a CFD simulation in the work of Arzamendi et al. [29]. They observed that for a constant reforming space velocity the introduction of combustion flow increased the overall temperature in the reactor, causing a higher conversion of methanol. The temperature differences also depended on the integration design. Arzamendi et al. [29] studied different feed designs for reforming and combustion flows. They carried out a simulation in which they studied three ways of coupling the flows of both reactions: parallel, countercurrent and crossed. The advantage of using the cross flow compared to the others was the ease of the block piping connection system. They observed that for the same reaction conditions, parallel flow was the most convenient from the isothermicity point of view because they obtained a maximum temperature difference of $4{ }^{\circ} \mathrm{C}$. However, 
with the countercurrent flow, the largest temperature difference in the block was obtained, reaching a difference of $19^{\circ} \mathrm{C}$ and the arrangement used in our blocks, cross-flow, showed a temperature difference of $7{ }^{\circ} \mathrm{C}$. Our experimental results (Figure 9) showed excellent agreement with the values predicted in the modeling work previously carried out by Arzamendi et al. [29]. In our less favorable case, with $460 \mathrm{mg}$ catalyst load, $\Delta \mathrm{T}_{\mathrm{MSR}}$ was about $8 \mathrm{~K}$ and $\Delta \mathrm{T}_{\mathrm{COMB}}$ was about $16 \mathrm{~K}$. This confirms the good coupling of the methanol steam reforming and the methanol combustion.

\section{Conclusions}

A microchannel reformer/combustor was designed for methanol steam reforming. The obtained results show that:

- After the optimization of the washcoating process (slurry and procedure) excellent results of load, homogeneity and adhesion have been achieved on microchannel blocks. Successful and well-performing coatings of $\mathrm{Pd} / \mathrm{ZnO}$ reforming catalyst and $\mathrm{Pd} / \mathrm{Al}_{2} \mathrm{O}_{3}$ combustion catalyst were produced.

- An experimental system has been designed and fine-tuned allowing the heat losses of the system to be estimated and to compensate for them by means of electric heating cartridges. In this way, the heat necessary for the reforming reaction was provided with the methanol combustion thanks to a temperature and flow cascade controller developed. Thus, the coupling of both reactions in a block of microchannels without the interference caused by the significant heat losses due to the small size of the laboratory microreactor could be studied.

- The power provided to keep the reactor temperature was much higher than that required for the methanol reforming reaction and the sensible heat necessary to heat up the feed, due to the heat losses, dissipated to the hot box in which the reactor was located.

- The heat loss increased slightly with the steam reforming temperature, being relatively constant varying catalyst loading or reforming fuel flow rate.

- The methanol combustion is a very quick reaction and takes place near the microcombustor inlet. However, the microchannel reactor conductivity was able to maintain the methanol steam reforming reaction practically isothermal when coupling reforming and combustion reaction.

- When the reforming reaction was compensated by the combustion reaction and the heat losses by the electric heating, an isothermal behavior of the microchannels reactor was observed. In the less favorable case, $\Delta \mathrm{T}_{\mathrm{MSR}}$ was about $8 \mathrm{~K}$ and $\Delta \mathrm{T}_{\mathrm{COMB}}$ was about $16 \mathrm{~K}$, confirming the good coupling of both reactions.

Supplementary Materials: The following are available online at https:/ / www.mdpi.com/article/10 .3390 /reactions2020007/s1, Figure S1: (a) Microreactor during insulation installation. (b) Microreactor with insulating shell, heater cartridges and six thermocouples. (c) Microreactor with the insulating shell and fluid connections installed in the hot box of the commercial mother reactor.

Author Contributions: Conceptualization, O.S. and M.M.; funding acquisition, O.S. and M.M.; investigation, I.V., I.P.-M. and O.S.; supervision, O.S. and I.L.; writing—original draft preparation, O.S. and M.M.; writing-review and editing, O.S. and M.M. All authors have read and agreed to the published version of the manuscript.

Funding: This research was funded by MICINN/FEDER grant numbers RTI2018-096294-B-C32 and CTQ2015-73901-JIN and by the Basque Government grant number IT1069-16.

Acknowledgments: I.P.-M. acknowledges the Basque Government for PhD scholarship (PRE_2014_1_141). The authors are thankful for the technical and human support provided by SGIker of UPV/EHU (X-ray diffraction measurements).

Conflicts of Interest: The authors declare no conflict of interest. 


\section{References}

1. Holladay, J.D.; Hu, J.; King, D.L.; Wang, Y. An overview of hydrogen production technologies. Catal. Today 2009, 139, 244-260. [CrossRef]

2. Sanz, O.; Velasco, I.; Perez-Miqueo, I.; Poyato, R.; Odriozola, J.A.; Montes, M. Intensification of hydrogen production by methanol steam reforming. Int. J. Hydrog. Energy 2016, 41, 5250-5259. [CrossRef]

3. Palo, D.R.; Dagle, R.A.; Holladay, J.D. Methanol steam reforming for hydrogen production. Chem. Rev. 2007, $107,3992-4021$. [CrossRef] [PubMed]

4. Sanz, O.; Velasco, I.; Reyero, I.; Legorburu, I.; Arzamendi, G.L.; Gandía, M.; Montes, M. Effect of the thermal conductivity of metallic monoliths on methanol steam reforming. Catal. Today 2016, 273, 131-139. [CrossRef]

5. Pan, L.; Wang, S. Methanol steam reforming in a compact plate-fin reformer for fuel-cell systems. Int. J. Hydrog. Energy 2005, 30, 973-979. [CrossRef]

6. Yu, X.; Tu, S.-T.; Wang, Z.; Qi, Y. Development of a microchannel reactor concerning steam reforming of metanol. Chem. Eng. J. 2006, 116, 123-132. [CrossRef]

7. Park, G.-G.; Seo, D.J.; Park, S.-H.; Yoon, Y.-G.; Kim, C.-S.; Yoon, W.-L. Development of microchannel methanol steam reformer. Chem. Eng. J. 2004, 101, 87-92. [CrossRef]

8. Kolb, G.; Hessel, V. Micro-structured reactors for gas phase reactions. Chem. Eng. J. 2004, 98, 1-38. [CrossRef]

9. Uriz, I.; Arzamendi, G.; Diéguez, P.M.; Echave, F.J.; Sanz, O.; Montes, M.; Gandía, L.M. CFD analysis of the effects of the flow distribution and heat losses on the steam reforming of methanol in catalytic (Pd/ZnO) microreactors. Chem. Eng. J. 2014, 238, 37-44. [CrossRef]

10. Holladay, J.D.; Jones, E.O.; Phelps, M.; Hu, J. Microfuel processor for use in a miniature power supply. J. Power Sources 2002, 108, 21-27. [CrossRef]

11. Kim, T. Micro methanol reformer combined with a catalytic combustor for a PEM fuel cell. Int. J. Hydrog. Energy 2009, 34, 6790-6798. [CrossRef]

12. Won, J.Y.; Jun, H.K.; Jeon, M.K.; Woo, S.I. Performance of microchannel reactor combined with combustor for methanol steam reforming. Catal. Today 2006, 111, 158-163. [CrossRef]

13. Chein, R.-Y.; Chen, Y.-C.; Chang, C.-M.; Chung, J.N. Experimental study on the performance of hydrogen production from miniature methanol-steam reformer integrated with Swiss-roll type combustor for PEMFC. Appl. Energy 2013, 105, 86-98. [CrossRef]

14. Jin, J.; Kwon, S. Fabrication and performance test of catalytic micro-combustors as a heat source of methanol steam reformer. Int. J. Hydrog. Energy 2010, 35, 1803-1811. [CrossRef]

15. Yoshida, K.; Tanaka, S.; Hiraki, H.; Esashi, M. A micro fuel reformer integrated with a combustor and a microchannel evaporator. J. Micromech. Microeng. 2006, 16, S191-S197. Available online: https://iopscience.iop.org/article/10.1088/0960-1317/16/9/S04 (accessed on 6 April 2021). [CrossRef]

16. Cao, C.; Xia, G.; Holladay, J.; Jones, E.; Wang, Y. Kinetic studies of methanol steam reforming over Pd/ZnO catalyst using a microchannel reactor. Appl. Catal. A Gen. 2004, 262, 19-29. [CrossRef]

17. Suh, J.-S.; Lee, M.-T.; Greif, R.; Grigoropoulos, C.P. Transport phenomena in a steam-methanol reforming microreactor with internal heating. Int. J. Hydrog. Energy 2009, 34, 314-322. [CrossRef]

18. Chein, R.; Chen, Y.-C.; Chung, J.N. Axial heat conduction and heat supply effects on methanol-steam reforming performance in micro-scale reformers. Int. J. Heat Mass Transf. 2012, 550, 3029-3042. [CrossRef]

19. Reuse, P.; Renken, A.; Haas-Santo, K.; Gorke, O.; Schubert, K. Hydrogen production for fuel cell application in an autothermal micro-channel reactor. Chem. Eng. J. 2004, 101, 133-141. [CrossRef]

20. de Wild, P.J.; Verhaak, M.J.F.M. Catalytic production of hydrogen from methanol. Catal. Today 2000, 60, 3-10. [CrossRef]

21. Tadbir, M.A.; Akbari, M.H. Methanol steam reforming in a planar wash coated microreactor integrated with a micro-combustor. Int. J. Hydrog. Energy 2011, 36, 12822-12832. [CrossRef]

22. Stefanidis, G.D.; Vlachos, D.G. High vs. low temperature reforming for hydrogen production via microtechnology. Chem. Eng. Sci. 2009, 64, 4856-4865. [CrossRef]

23. Chein, R.-Y.; Chen, Y.-C.; Chung, J.N. Thermal resistance effect on methanol-steam reforming performance in micro-scale reformers. Int. J. Hydrog. Energy 2012, 37, 250-262. [CrossRef]

24. Stefanidis, G.D.; Vlachos, D.G. Intensification of steam reforming of natural gas: Choosing combustible fuel and reforming catalyst. Chem. Eng. Sci. 2010, 65, 398-404. [CrossRef]

25. Chein, R.-Y.; Chen, Y.-C.; Lin, Y.-S.; Chung, J.N. Hydrogen production using integrated methanol-steam reforming reactor with various reformer designs for PEM fuel cells. Int. J. Energy Res. 2012, 36, 466-476. [CrossRef]

26. Holladay, J.D.; Jones, E.O.; Dagle, R.A.; Xia, G.G.; Cao, C.; Wang, Y. High efficiency and low carbon monoxide micro-scale methanol processors. J. Power Sources 2004, 131, 69-72. [CrossRef]

27. Shah, K.; Besser, R.S. Key issues in the microchemical systems-based methanol fuel processor: Energy density, thermal integration, and heat loss mechanisms. J. Power Sources 2007, 166, 177-193. [CrossRef]

28. Shah, K.; Besser, R.S. Understanding thermal integration issues and heat loss pathways in a planar microscale fuel processor: Demonstration of an integrated silicon microreactor-based methanol steam reformer. Chem. Eng. J. 2008, 135, S46-S56. [CrossRef] 
29. Arzamendi, G.; Diéguez, P.M.; Montes, M.; Centeno, M.A.; Odriozola, J.A.; Gandía, L.M. Integration of methanol steam reforming and combustion in a microchannel reactor for H2 production: A CFD simulation study. Catal. Today 2009, 143, 25-31. [CrossRef]

30. Sá, S.; Silva, H.; Brandão, L.; Sousa, J.M.; Mendes, A. Catalysts for methanol steam reforming-A review. Appl. Catal. B Environ. 2010, 99, 43-57. [CrossRef]

31. Zwinkels, M.F.M.; Järås, S.G.; Menon, P.G.; Griffin, T.A. Catalytic materials for high-temperature combustion. Catal. Rev. 1993, 35, 319-358. [CrossRef]

32. Cruz, S.; Sanz, O.; Poyato, R.; Laguna, O.H.; Echave, F.J.; Almeida, L.C.; Centeno, M.A.; Arzamendi, G.; Gandia, L.M.; SouzaAguiar, E.F.; et al. Design and testing of a microchannel reactor for the PROX reaction. Chem. Eng. J. 2011, 167, 634-642. [CrossRef]

33. Velasco-Ortiz, I. Catalizadores Estructurados y Reactores de Microcanales para el Reformado de Metanol. Ph.D. Thesis, University of the Basque Country, San Sebastian, Spain, 2015.

34. Echave, F.J.; Sanz, O.; Montes, M. Washcoating of microchannel reactors with PdZnO catalyst for methanol steam reforming. Appl. Catal. A Gen. 2014, 474, 159-167. [CrossRef]

35. Almeida, L.C.; Echave, F.J.; Sanz, O.; Centeno, M.A.; Arzamendi, G.; Gandía, L.M.; Sousa-Aguiar, E.F.; Odriozola, J.A.; Montes, M. Fischer-Tropsch synthesis in microchannels. Chem. Eng. J. 2011, 167, 536-544. [CrossRef]

36. Echave, F.J.; Sanz, O.; Velasco, I.; Odriozola, J.A.; Montes, M. Effect of the alloy on micro-structured reactors for methanol steam reforming. Catal. Today 2013, 213, 145-154. [CrossRef]

37. He, Z.; He, Z.; Wang, D.; Bo, Q.; Fan, T.; Jiang, Y. Mo-modified $\mathrm{Pd} / \mathrm{Al}_{2} \mathrm{O}_{3}$ catalysts for benzene catalytic combustion. Int. J. Environ. Sci. 2014, 26, 1481-1487. [CrossRef]

38. Mateos-Pedrero, C.; Silva, H.; Pacheco-Tanaka, D.A.; Liguori, S.; Iulianelli, A.; Basile, A.; Mendes, A. CuO/ZnO catalysts for methanol steam reforming: The role of the support polarity ratio and surface area. Appl. Catal. B Environ. 2015, 174-175, 67-76. [CrossRef]

39. Dagle, R.A.; Platon, A.; Palo, D.R.; Datye, A.K.; Vohs, J.M.; Wang, Y. PdZnAl catalysts for the reactions of water-gas-shift, methanol steam reforming, and reverse-water-gas-shift. Appl. Catal. A Gen. 2008, 342, 63-68. [CrossRef]

40. Lo, K.-F.; Wong, S.-C. A passively-fed methanol steam reformer with catalytic combustor heater. Int. J. Hydrog. Energy 2011, 36, 10719-10726. [CrossRef]

41. Kwon, O.J.; Yoon, D.H.; Kim, J.J. Silicon-based miniaturized reformer with methanol catalytic burner. Chem. Eng. J. 2008, 140, 466-472. [CrossRef] 